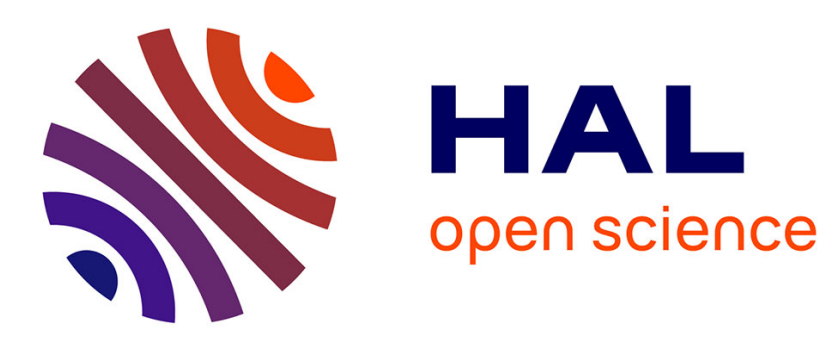

\title{
Green foams for microwave absorbing applications: Synthesis and characterization
}

Vincent Laur, Ratiba Benzerga, Ronan Lebullenger, L. Le Gendre, G. Lanoë, A. Sharaiha, P Quéffélec

\section{> To cite this version:}

Vincent Laur, Ratiba Benzerga, Ronan Lebullenger, L. Le Gendre, G. Lanoë, et al.. Green foams for microwave absorbing applications: Synthesis and characterization. Materials Research Bulletin, 2017, 96, pp.100-106. 10.1016/j.materresbull.2017.01.052 . hal-01468971

\section{HAL Id: hal-01468971 \\ https://hal.science/hal-01468971}

Submitted on 8 Jun 2018

HAL is a multi-disciplinary open access archive for the deposit and dissemination of scientific research documents, whether they are published or not. The documents may come from teaching and research institutions in France or abroad, or from public or private research centers.
L'archive ouverte pluridisciplinaire HAL, est destinée au dépôt et à la diffusion de documents scientifiques de niveau recherche, publiés ou non, émanant des établissements d'enseignement et de recherche français ou étrangers, des laboratoires publics ou privés. 


\section{Green foams for microwave absorbing applications: synthesis and}

\section{characterization}

V. Laur ${ }^{1}$, R. Benzerga ${ }^{2, *}$, R. Lebullenger ${ }^{3}$, L. Le Gendre ${ }^{2}$, G. Lanoë ${ }^{2,3}$, A. Sharaiha ${ }^{2}$, P. Queffelec ${ }^{1}$

${ }^{1}$ Laboratoire des Sciences et Techniques de l'Information, de la Communication et de la Connaissance, Université de Bretagne Occidentale, 6 avenue Le Gorgeu, CS93837, 29238 Brest Cedex 3, France

${ }^{2}$ Institut d'Electronique et de Télécommunications de Rennes, Université de Rennes 1, IUT de Saint Brieuc, 18 rue Henri Wallon, 22004 Saint-Brieuc, France

${ }^{3}$ Institut des Sciences Chimiques de Rennes, Université de Rennes 1, 263, avenue du Général Leclerc, 35042 Rennes Cedex. France

* Corresponding author: R. Benzerga, ratiba.benzerga@univ-rennes1.fr

\section{Graphical abstract}
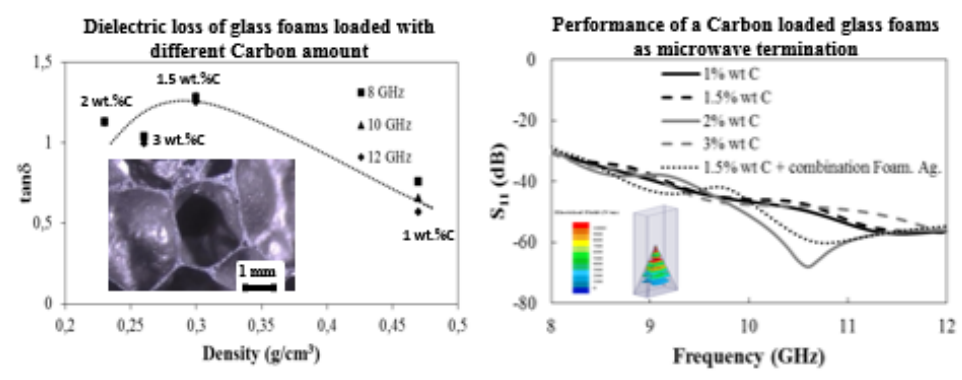


\title{
Highlights
}

- Carbon-filled CRT-based glass foams have been studied for microwave application

- The dielectric loss of a glass foam made with $1.5 \%$ wt. C are tan $\delta=1.4 @ 9 \mathrm{GHz}$.

- A combination of $\mathrm{C}, \mathrm{MnO}_{2}, \mathrm{AlN}$ and $\mathrm{TiO}_{2}$ as foaming agent reduces the foam density

- Glass foams properties depend both on their carbon content and their densities

- Residual C in foam made with 1.5\%C induces a shielding efficiency of $18 \mathrm{~dB} / \mathrm{cm} @ 12 \mathrm{GHz}$

- Simulated reflection coefficient of pyramidal absorbers are lower than -30dB

\begin{abstract}
This study deals with the dielectric properties of recycled glass foams and their use as microwave absorbers. Glass wastes from Cathode Ray Tube have been used to produce foams by heating a mixture consisting of glass cullet and foaming agents (carbon or a combination of carbon, $\mathrm{TiO}_{2}, \mathrm{MnO}_{2}$ and $\mathrm{AlN}$ ). As only part of the carbon introduced into the initial load oxidizes and contributes to the foaming process, the residual fraction acts as an electromagnetic absorber. The effect of the carbon load rate on the foams density and microwave properties was studied. These materials present a low permittivity and high dielectric losses in X-band. Foams density mainly controls the dielectric properties. Carbon-based glass foams show a great potential as microwave absorbers with a shielding effectiveness of $20 \mathrm{~dB} / \mathrm{cm}$ at $12 \mathrm{GHz}$. Moreover, a tradeoff between the density and shielding efficiency can be achieved by controlling the load rate of carbon.
\end{abstract}

Keywords: Dielectric properties; Glasses; Inorganic compounds; Glass foams; Electromagnetic absorption.

\section{Introduction}


Recycling materials is a burning issue in our modern societies. Indeed, with the continuous improvement of people's living standard, the needs in raw materials increase whereas resources drastically decrease. Moreover the reintroduction of end-of-life materials in the production chain also reduces global energy consumption, which directly reduces greenhouse gas emissions. In this context, since early seventies, recycling chains of glass wastes were developed with a great success and glass containers (bottles) are now widely recycled. That way, the cullet resulting from the collection of used liquid-food packaging in the form of bottles and jars covers $70 \%$ of the glass industry needs in terms of raw materials. As the melting temperature of the cullet $\left(1000^{\circ} \mathrm{C}\right)$ is lower than that of the raw materials $\left(1500^{\circ} \mathrm{C}\right)$, the glass industry's carbon balance is significantly improved [1-2]. Other types of glass compositions, often polluted with heavy metals, pose a tougher problem. Indeed, as hazardous materials, glass wastes from electronic industry (e-wastes) should be treated in specific recycling process [3]. This is particularly the case of cathode ray tubes (CRT) found in older style TV screens and monitors that can be neither recycled in a closed loop production process due to the termination of this technology nor reintroduced as a cullet in the production line of conventional hollow glasses due to their high heavy metal content $(\mathrm{Pb}, \mathrm{Ba}, \mathrm{Sr})$ [4]. Foam glass manufacture is a promising mode for re-using CRT glasses: depending on the foaming process, this cellular material combines low density, low thermal conductivity, excellent thermal stability and high rigidity [1-8]. As it has been demonstrated by leaching tests that the fraction of lead released, in end-use conditions, from foam glass was lower than the statutory limit [4], this material can be inserted in a commercial device. As the primary function of those leaded glasses was to block electromagnetic (EM) radiation in CRTs, we focused our attention on EM absorptive properties of those glass foams based on cathode ray tube cullet. Inorganic additives (powders or fibers) can be used to reinforce the shielding properties in a specific spectral range [3, 
9-11]. Indeed, when Aluminum Nitride (AIN) or Silicon Carbide (SiC) are used to initiate the foaming process, part of those adds do not chemically react with the glassy matrix and, as a result, glass foams present a low permittivity together with low dielectric losses [7]. In the same way, when Carbon (C) is used as the foaming agent, high dielectric losses are observed making of these foams a good candidate for microwave absorbing applications [7, 11].

In this paper, we studied the microwave behavior of glass foams for different load rates of carbon. In a first part, the process of elaboration will be presented. We especially focused on the impact of the load rate and nature of the foaming agent on the density of the foams. Indeed, an original combination of foaming agent based on the results of previous studies [8, 12-13] has been tested to reach a low-density C-doped foam glass. Then, the microwave properties of these foams will be presented and their potentiality for microwave absorbing applications will be discussed.

\section{Materials and foam manufacturing}

The elaboration process of the foams is illustrated in Fig. 1 and the synthesis parameters are summarized in Table 1. As a first step, the cullet and the foaming agent (C for example) are thoroughly mixed and grinded to produce an homogeneous batch (Fig 1.a). When this mixture reaches a temperature close to the softening temperature of the glass, the foaming agent reacts to release gaseous products that is the key factor of the expansion (Fig 1.b). A short chemical reaction time results in a partial consumption of the foaming agent [8] and the unreacted part (Fig 1.c), after cooling down to room temperature, acts as EM-absorbent dispersed in a light matrix.

In this study, the CRT cullet is a mixture of panel (front part) and funnel (rear part) glasses. The weight ratio of the mixture is near $2 / 3$ (panel) and1/3 (funnel). Front glass is typically a $\mathrm{SiO}_{2}$ based glass containing barium and strontium oxide, while funnel glass is also a $\mathrm{SiO}_{2}$ based glass but 
containing around $20 \%$ in lead oxide. So, the CRT cullet is a mixture of silicate glasses containing between 5 to $7 \mathrm{wt} \%$ in lead oxide. This CRT glass cullet is supplied by Environment Recycling, a French company expert in WEEE dismantlement. A crushing step is achieved on CRT mixture with a Gabrielli Fast-Mill planetar mortar with alumina balls, to obtain a fine powder whose granulometry is lower than $125 \mu \mathrm{m}$. The CRT cullet pre-dried at $150^{\circ} \mathrm{C}$ for 12 hours is milled together with the carbon foaming agent (from Ventron Alfa Produdkte with a granulometry of 325 meshes / $44 \mu \mathrm{m})$ or a combination of Carbon $(\mathrm{C})$, Manganese dioxide $\left(\mathrm{MnO}_{2}\right)$, Aluminum nitride $(\mathrm{AlN})$ and Titanium dioxide $\left.\left(\mathrm{TiO}_{2}\right)\right)$. Then, the resulting mixture is placed into a heat resistant steel mold and heated at $850^{\circ} \mathrm{C}$ during $30 \mathrm{~min}$. At this temperature, bubbles occur as the carbon is oxidized to $\mathrm{CO}_{2}$ or as the nitride ions are oxidized in dinitrogen or as dioxygen results from the $\mathrm{MnO}_{2}$ to $\mathrm{Mn}_{2} \mathrm{O}_{3}$ reduction [6]. Note that in the combination of foaming agents, $\mathrm{TiO}_{2}$ acts as a sacrificial oxidant in order to promote the gas-releasing reaction.

\section{Methods of characterization}

For the microstructure observation, and as given the millimeter-sized porosities of the foam glasses, the structure of the samples was observed by a Leica camera (DFC295) coupled with a stereomicroscope Leica MS5. The density of the glass foams was calculated using the measured mass and volume of each sample.

For the dielectric characterization, the properties of the foams were extracted by a reflectiontransmission method between 8 and $12 \mathrm{GHz}$ (X-band). This technique is based on a quasi-static analysis of a rectangular waveguide loaded by a sample to be characterized [14]. After a ThruReflect-Line calibration [14], S-parameters of the empty waveguide are measured with a vector network analyzer (VNA Agilent E8364A) in order to take into account metallic losses. The glass 
foam sample is cut to the dimension of the waveguide $(22.86 \mathrm{~mm} \times 10.16 \mathrm{~mm} \times 20 \mathrm{~mm})$ and inserted for measurements. The modifications of S-parameters (both amplitude and phase) are analyzed by a Nicolson-Ross-Weir procedure [15-16] in order to extract the complex permittivity $\left(\varepsilon^{*}=\varepsilon^{\prime}-\mathrm{j} \varepsilon^{\prime \prime}\right)$ of the samples.

\section{Results and discussion}

\subsection{Effect of the foaming agent content}

To check the influence of materials density on the electromagnetic properties we prepared samples with different amount of carbon [0.5 wt $\%-5 \mathrm{wt} \%]$ on the one hand, and with a mixture of carbon, $\mathrm{TiO}_{2}, \mathrm{AlN}$ and $\mathrm{MnO}_{2}$ on the other. Fig. 2 shows the influence of the carbon foaming agent content on the apparent density of the foams. As previously observed [17-18], this curve presents a minimum density for a carbon load rate between 2 and $3 \mathrm{wt} \%$. Indeed, a low C concentration results in a moderate amount of gas release that leads to weakly expanded parts $\left(\mathrm{d}_{0.5 \mathrm{wt}} \mathrm{C}=0.58 \mathrm{~g} / \mathrm{cm}^{3}\right)$. On the other hand, a carbon overload generates an internal gas pressure that the viscous liquid phase cannot retain. In that case, too many bubbles grow and coalesce leading to the collapse of the foam $\left(\mathrm{d}_{5 \% \mathrm{C}}=1.76 \mathrm{~g} / \mathrm{cm}^{3}\right)$

Fig. 3 presents images of the foams obtained with different carbon content which confirm this bubbles growth process. Up to $1.5 \mathrm{C} w \mathrm{t} \%$, one can see an homogeneous pore size distribution resulting from the trapping of near-spherical bubbles whose diameters range from 0.5 to $2 \mathrm{~mm}$. The move to higher $\mathrm{C}$ load, $2 \mathrm{wt} \%$ and $3 \mathrm{wt} \%$, leads to larger pores resulting from gas bubbles collapse and interconnection. That way, for a glass foam prepared with $3 \mathrm{wt} \%$ of carbon, the pore size lies within a range of 1 to $5 \mathrm{~mm}$ approximately. For excessive amount of carbon ( $5 \mathrm{wt} \%)$, the growth in 
the number and size of the $\mathrm{CO}_{2}$ gas bubbles reduces the cell wall thickness until the collapse of the foam. In that case, after cooling down to room temperature, one can see (Fig. 3) deformed bubbles residues trapped in the collapsed glassy matrix.

The density of the foam can be reduced by using a combination of foaming agents. Indeed, in addition to $1.5 \mathrm{wt} \%$ of carbon, a combination of $\mathrm{MnO}_{2}(4 \mathrm{wt} \%)$, $\mathrm{AlN}(2 \mathrm{wt} \%)$ and $\mathrm{TiO}_{2}(2 \mathrm{wt} \%)$ makes it possible to half the density of the resulting foam. Micrographs illustrate the increase of the pore diameters in this case (Fig. 4). This increase in pore size is logically accompanied by a reduction in the thickness of the cell walls to a minimum of $20 \mu \mathrm{m}$ which is still above the critical thickness of rupture $(1-20 \mathrm{~nm})[6]$.

4.2 Microwave characterizations and applications

Fig. 5.a presents the evolution of the real part of the permittivity, as a function of the frequency, for load rates of carbon between 1 and $3 \mathrm{wt} \%$. From a general point of view, C-based glass foams present a dispersive behavior. For example, when a $1 \mathrm{wt} \%$ load rate is considered, the permittivity decreases from 4.5 at $8 \mathrm{GHz}$ to 3.7 at $12 \mathrm{GHz}$. Dielectric losses $\left(\tan \delta=\varepsilon{ }^{\prime \prime} / \varepsilon\right.$ ') of the samples are very high (Fig. 5.b) with a maximum value of 1.4 at $9 \mathrm{GHz}$ for a $1.5 \mathrm{wt} \%$ load rate of carbon. However, it appears difficult to directly link the dielectric properties of the samples to the load rate of carbon because of the differences in density between the expanded foams.

Moreover, the very high losses observed on the samples associated with their porous structure suggest that the losses may be due to moisture absorption. Indeed, the high level of porosity of these materials can be accompanied by some water molecules adsorption which may thus be contributing to the microwave absorption. In order to address this point, all samples were oven-dried at $60^{\circ} \mathrm{C}$ for 18 hours. Measurements before and after drying at $60^{\circ} \mathrm{C}$ show that microwave absorption is not due 
to moisture absorption on the foam surface but to its intrinsic high dielectric losses. Fig. 6 presents an example of these measurements: S-parameters of the rectangular waveguide loaded with a 1 $\mathrm{wt} \%$ carbon-loaded glass foam (sample length $=10.06 \mathrm{~mm}$ ). This figure presents exactly the same S-parameters for this sample before and after drying step. A very low level of transmission $\left(\mathrm{S}_{21}\right)$, lower than $-19 \mathrm{~dB}$, is observed over the frequency band of measurement.

Fig. 7 shows the evolution of the dielectric properties of the glass foams as a function of the density. It appears that dielectric properties are mainly correlated with the density of the resulting foams. Permittivity increases proportionately with density whereas losses show a maximum value for a $1.5 \mathrm{wt} \% \mathrm{C}$ load rate $\left(\mathrm{d}_{1.5 \mathrm{wt} \% \mathrm{C}}=0.30 \mathrm{~g} / \mathrm{cm}^{3}\right)$. A low value of permittivity and high dielectric losses are generally required to get highly efficient microwave absorber materials. As a consequence, the optimum carbon load rate could be chosen around $1.5 \mathrm{wt} \%$.

Lossy materials with a low permittivity are of interest for shielding applications. The shielding efficiency (SE) is defined by the following equation:

$$
S E=S_{21} / l \text { in } \mathrm{dB} / \mathrm{cm}
$$

where $S_{21}$ is the amplitude of the transmission parameters and $l$ the length of the sample.

The shielding efficiency as a function of frequency for different load rate of carbon is presented in Fig. 8. SE is higher than $13 \mathrm{~dB} / \mathrm{cm}$ for all the foams. A $1 \mathrm{wt} \%$-carbon loaded foam provides the best shielding efficiency with a value higher than $19 \mathrm{~dB} / \mathrm{cm}$ over the whole frequency band.

Now, if we take into account the density of the materials, one could define a new quantity, called here Shielding Efficiency Relative to Mass (SERM):

$$
S E R M=S E /(d \times S) \text { in } \mathrm{dB} / \mathrm{g}
$$

where $\mathrm{d}$ is the density of the foam and $\mathrm{S}$ the section of the rectangular waveguide. 
SERM reveals the tradeoff between mass and efficiency of absorption for a given material. Fig. 9 shows the evolution of SERM for different load rate of carbon in the foam. Load rates of $1.5 \mathrm{wt} \%$ and $2 \mathrm{wt} \%$ give the best results with a SERM value of about $25 \mathrm{~dB} / \mathrm{g}$ at $10 \mathrm{GHz}$. These foams seem to be the most efficient, tailored for systems in which the mass is a critical issue.

We pointed out earlier that using a combination of foaming agents $\left(\mathrm{C}, \mathrm{AlN}, \mathrm{MnO}_{2}\right.$ and $\left.\mathrm{TiO}_{2}\right)$ helps to reduce the glass foams density while keeping an efficient electromagnetic absorbent C-based fraction. Fig. 10.a compares dielectric losses of the samples prepared using only carbon or a combination of foaming agents. The same carbon amount of $1.5 \mathrm{wt} \%$ was used for these two samples. Quite similar dielectric losses are observed over the frequency band between 8 and 12 GHz. Indeed, it appears possible to keep high dielectric losses while strongly reducing the density of the foam by using such a combination of foaming agents. One should note that, due to the pairing of high dielectric losses and low density, a combination of foaming agents $\left(\mathrm{C}, \mathrm{AlN}, \mathrm{MnO}_{2}\right.$ and $\mathrm{TiO}_{2}$ ) enables to increase the SERM. SERM values of $25 \mathrm{~dB} / \mathrm{g}$ and $29.5 \mathrm{~dB} / \mathrm{g}$ are obtained at 10 $\mathrm{GHz}$ (Fig. 10.b) for, respectively, foam achieved with only carbon as foaming agent $(1.5 \mathrm{wt} \%)$ and the foam achieved with the combination of foaming agents $\left(1.5 \mathrm{wt} \% \mathrm{C}, 4 \mathrm{wt} \% \mathrm{MnO}_{2}, 2 \mathrm{wt} \% \mathrm{AlN}\right.$ and $\left.2 \mathrm{wt} \% \mathrm{TiO}_{2}\right)$.

Finally, we simulated the performances of a microwave termination consisting of a pyramidal sample of foam inserted in a short-circuited X-band rectangular waveguide. Microwave terminations are devices that are usually integrated in telecommunications systems to protect the other devices from impedance mismatches or undesired electromagnetic radiations received by the antenna. These devices are usually realized by using pyramidal samples of polymer composites or lossy ceramics for low and high power applications respectively. 
We performed electromagnetic simulations of a $7 \mathrm{~cm}$ long pyramidal foam (Fig. 11). Amplitude of the electric field of the EM wave, inside the pyramidal absorber (Fig. 11.a), shows that the entire EM wave is absorbed before reaching the base of the pyramid. Simulated reflection coefficients are less than $-30 \mathrm{~dB}$ over the whole frequency band whatever the composition of the foam is (Fig. 11.b). These simulations demonstrate that carbon-based glass foams can be a good compromise between polymer composites which suffer from thermal limitations (i.e. low power handling capability) and lossy ceramics for which the weight and cost remain high.

\section{Conclusion}

We synthesized glass foams by using recycled cullet of cathode ray tube (CRT) and particles of carbon as foaming agent. As expected, the carbon load rate impacts the foaming process leading to a large range of foams density $\left[0.23-0.58 \mathrm{~g} / \mathrm{cm}^{3}\right]$. One can note that an excessive amount of carbon (i.e. $5 \mathrm{wt} \%)$ results in a complete collapse of the foam structure $\left(\mathrm{d}=1.76 \mathrm{~g} / \mathrm{cm}^{3}\right)$. We demonstrated that a combination of foaming agents $\left(\mathrm{C}, \mathrm{AlN}, \mathrm{MnO}_{2}\right.$ and $\left.\mathrm{TiO}_{2}\right)$ leads to highly porous glass foams with a density of $0.16 \mathrm{~g} / \mathrm{cm}^{3}$.

The microwave properties of these foams were extracted by using a rectangular waveguide method between 8 and $12 \mathrm{GHz}$. Carbon-based glass foams present dispersive dielectric properties at X-band with low permittivity values and high dielectric losses. Dielectric properties are mainly correlated to the density of the foams. That way, permittivity tends to increase with increasing density whereas dielectric loss reaches a maximum for a $1.5 \mathrm{wt} \%$ carbon loaded foam.

These materials present very effective properties for shielding applications. Indeed, shielding effectiveness reaches a value of $20 \mathrm{~dB} / \mathrm{cm}$ for a $1 \mathrm{wt} \%$ carbon load rate. For applications in which 
mass is a critical issue, $1.5 \mathrm{wt} \%$ or $2 \mathrm{wt} \%$ load rate seems to be the best compromise between mass and shielding efficiency.

Carbon-based glass foams are also a good candidate for the realization of cost-effective microwave terminations. Whatever the composition is, simulations of microwave terminations that integrate carbon-based glass foams demonstrated a return loss lower than $-30 \mathrm{~dB}$ over the X-band.

\section{References}

[1] J. Pasqualino, M. Meneses, F. Castells, The carbon footprint and energy consumption of beverage packaging selection and disposal, Journal of Food Engineering, 103 (2011) 357-365.

[2] A. Schmitz, J. Kaminski, B. M. Scalet, A. Soria, Energy consumption and CO2 emissions of the European glass industry, Energy Policy 39 (2011) 142-155.

[3] N. Singh, J. Li, X. Zeng, Global responses for recycling waste CRTs in e-waste, Waste Management (2016).

[4] P. G. Yot, F. O. Méar, Characterization of lead, barium and strontium leachability from foam glasses elaborated using waste cathode ray-tube glasses, Journal of Hazardous Materials 185 (2011) $236-241$.

[5] E.A. Yatsenko, B.M. Goltsman, V.A. Smolii, A.S.Kosarev, Foamed slag glass - eco-friendly insulating material based on slag waste, IEEE Int. Conf. Env. Elec. Eng. (2015).

[6] R.R. Petersen, J. König, Y. Yue, The mechanism of foaming and thermal conductivity of glasses foamed with $\mathrm{MnO}_{2}$, J. Non-Cryst. Solids 425 (2015) 74-82.

[7] R. Benzerga, V. Laur, R. Lebullenger, L. Le Gendre, S. Genty, A. Sharaiha, P. Queffelec, Waste-glass recycling: A step toward microwave applications, Mat. Res. Bull. 67 (2015) 261-265. 
[8] R. Lebullenger, S. Chenu, J.Rocherullé, O. Merdrigniac-Conanec, F. Cheviré, F. Tessier, A. Bouzaza, S. Brosillon ; Glass foam for environmental applications, J. Non-Cryst. Solids 356 (2010) $2562-2568$.

[9] O. V. kazmina, V. I. Suslyaev, M. A. Dushkina, V. A. Zhuravlev, K. V. Dorozhkin, Microwave absorption properties of foam glass material modified by adding ilmenite concentrate, PIERS Proceedings Prague Czech Republic July 6-9 (2015) 2684-2686.

[10] V. I. Suslyaev, O. V. Kazmina, B. S. Semukhin, Yu. P. Zemlyanukhin, M. A. Dushkina, Electrophysical characteristics of a foam glass crystal material, Russian Physics Journal 56-9 (2014) 990-996.

[11] J-F. Legendre, New radar absorbent material based of carboned foam glass application to pyramidal radar absorber, Microwave and optical technology letters, 57 (2015) 18-22.

[12] M. Tasserie, D. Bideau, P. Verdier, Y. Laurent, New expanded material based on industrial glass. II. Role and effect of the amount of an expansive additive on the characteristics of the material, Verre 6-2 (1992) 103-107.

[13] M. Tasserie, D. Bideau, Y. Laurent, P. Verdier, A new expanded material: optimization of the fabrication process, Journal of High Temperature Chemical Processes 1-3 (1992) 241-250.

[14] Y. Arbaoui, V. Laur, A. Maalouf, P. Queffelec, D. Passerieux, A. Delias, P. Blondy, Full 3D printed microwave termination: a simple and low-cost solution, IEEE Trans. Micr. Th. Techn. 64 (2015) 271-278.

[15] A. M. Nicolson, G. F. Ross, "Measurement of the Intrisic Properties of Materials by Timedomain Techniques", IEEE Transactions on Instrumentation and Measurement vol. 19 (1970) 377382. 
[16] W. B. Weir, "Automatic Measurement of Complex Dielectric Constant and Permeability at Microwave Frequencies", Proceedings of the IEEE vol. 62 (1974) 33-36.

[17] J. König, R.R. Petersen, Y. Yue, Fabrication of highly insulating foam glass made from CRT panel glass, Ceramics International 41 (2015) 9793-9800.

[18] Q. Zhang, F.He, H. Shu, Y. Qiao, S. Mei, M. Jin, J. Xie, Preparation of high strength glass ceramic foams from waste cathode ray tube and germanium tailings, Construction and Building Materials 111 (2016) 105-110. 


\section{List of Figure Captions:}

Fig. 1. Schematic illustration of the elaboration process: (a) Glass cullet and foaming agent mixture, (b) Foaming process at $850^{\circ} \mathrm{C}$ and (c) Resulting glass foam / C particles composite.

Fig. 2. Evolution of the foam density as a function of carbon amount

Fig. 3. Pictures of the glass foams for different carbon load rates.

Fig. 4. Microscope images of glass foams made with (a) $1.5 \mathrm{wt} \%$ of carbon only and (b) a mixing of 1.5 $\mathrm{wt} \%$ of of $\mathrm{C}, 4 \mathrm{wt} \%$ of $\mathrm{MnO}_{2}, 2 \mathrm{wt} \%$ of $\mathrm{AlN}$ and $2 \mathrm{wt} \%$ of $\mathrm{TiO}_{2}$ as foaming agents.

Fig. 5. (a) Real part of the permittivity and (b) loss tangent of glass foams loaded with different rates of carbon as a function of frequency

Fig. 6. Measured S-parameters of $1 \mathrm{wt} \%$ carbon-loaded glass foam (sample length $=11.2 \mathrm{~mm}$ ) before and after drying at $120^{\circ} \mathrm{C}$ during $24 \mathrm{~h}$.

Fig. 7. (a) Real part of the permittivity and (b) Loss tangent of glass foams with different rates of carbon as a function of density at different frequencies.

Fig. 8. Shielding Efficiency (SE) as a function of frequency for different carbon load rates. 
Fig. 9. Shielding Efficiency Relative to Mass (SERM) as a function of frequency for different carbon load rates.

Fig. 10. (a) Loss tangent and (b) Shielding Efficiency Relative to Mass (SERM) as a function of frequency of glass foams realized with $\mathrm{C}$ and a mixing of $\mathrm{C}, \mathrm{MnO}_{2}, \mathrm{AlN}$ and $\mathrm{TiO}_{2}$ as foaming agents (amount of carbon is $1.5 \mathrm{wt} \%$ for both samples).

Fig. 11. (a) Electromagnetic electrical field amplitude in a microwave rectangular waveguide termination made of a $7 \mathrm{~cm}$-long pyramidal $1 \%$ wt-loaded carbon glass foam and (b) Simulated reflection coefficient $\left(\mathrm{S}_{11}\right)$ of the device for different loaded glass foams. 

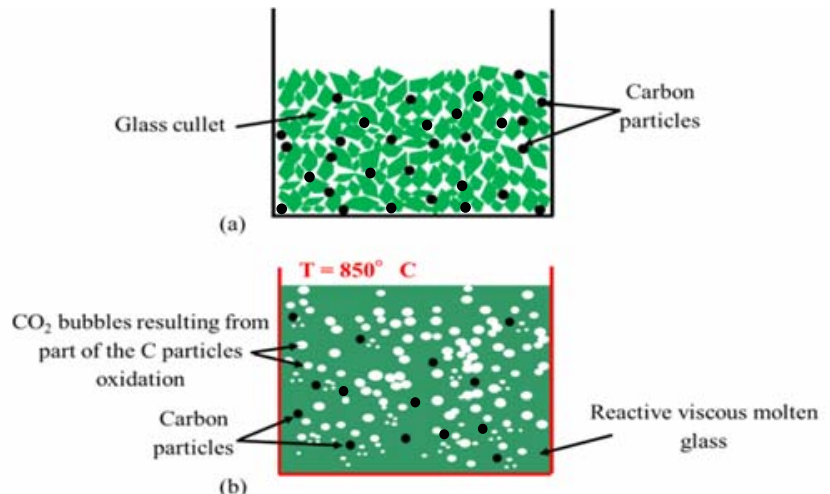

(b)

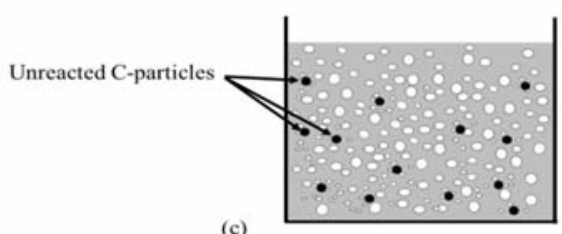

Fig. 1

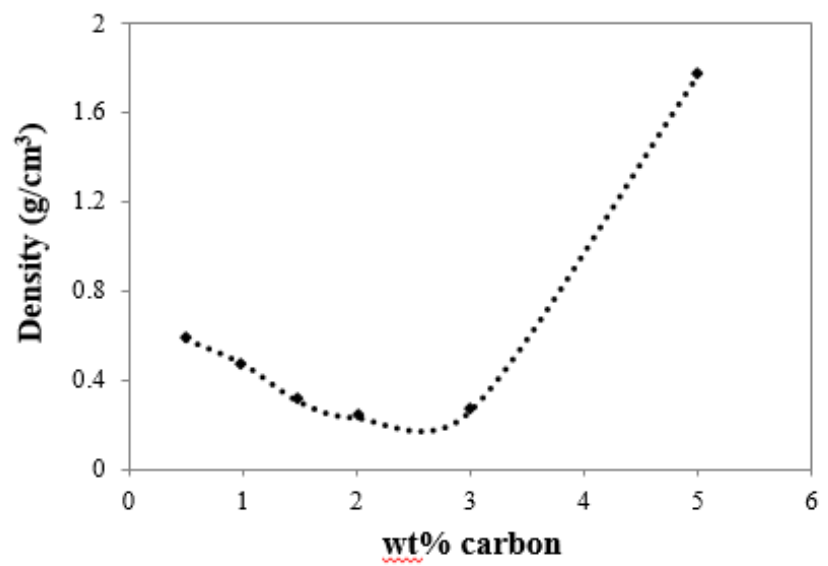

Fig 2 

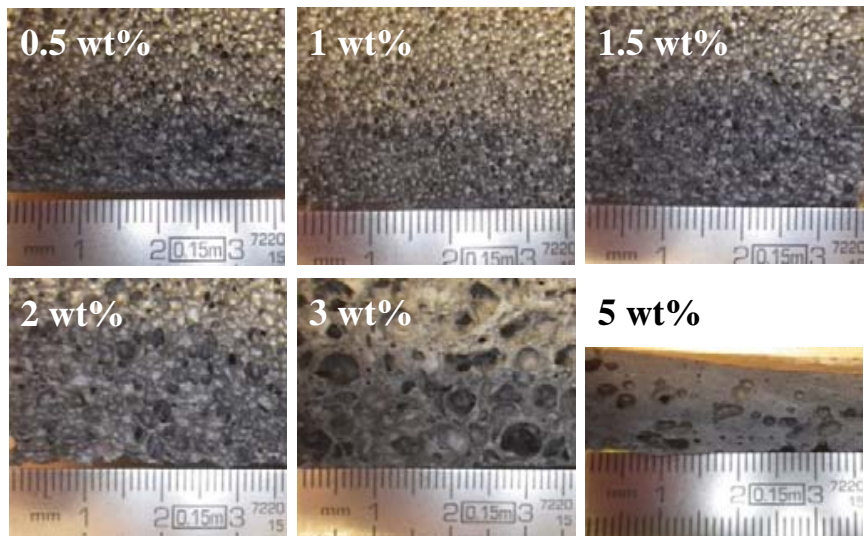

5 wt $\%$

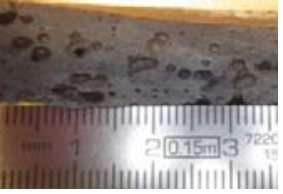

Fig. 3

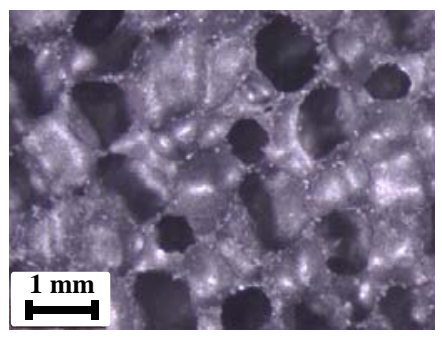

(a)

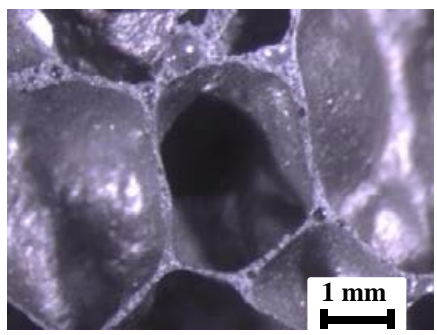

(b)

Figure. 4 


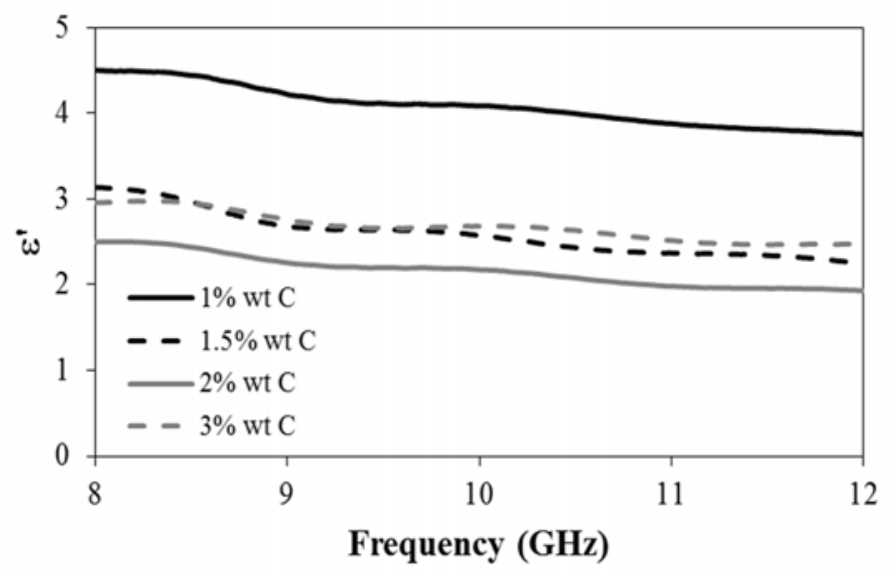

(a)

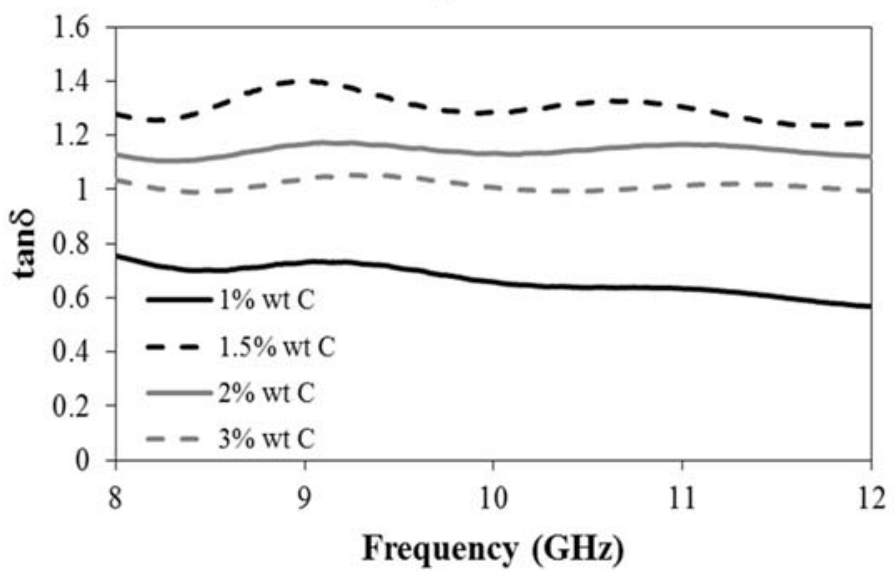

(b)

Fig. 5

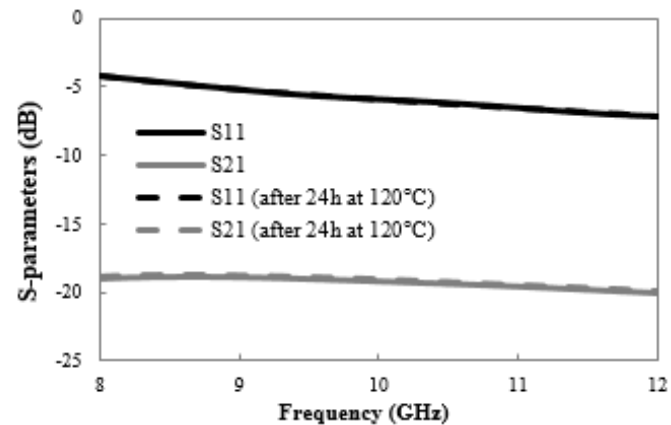

Fig 6 


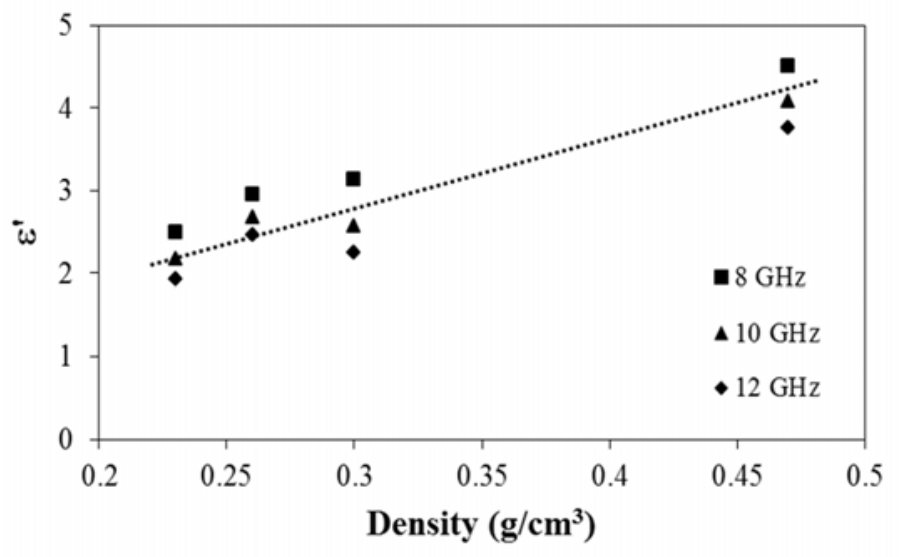

(a)

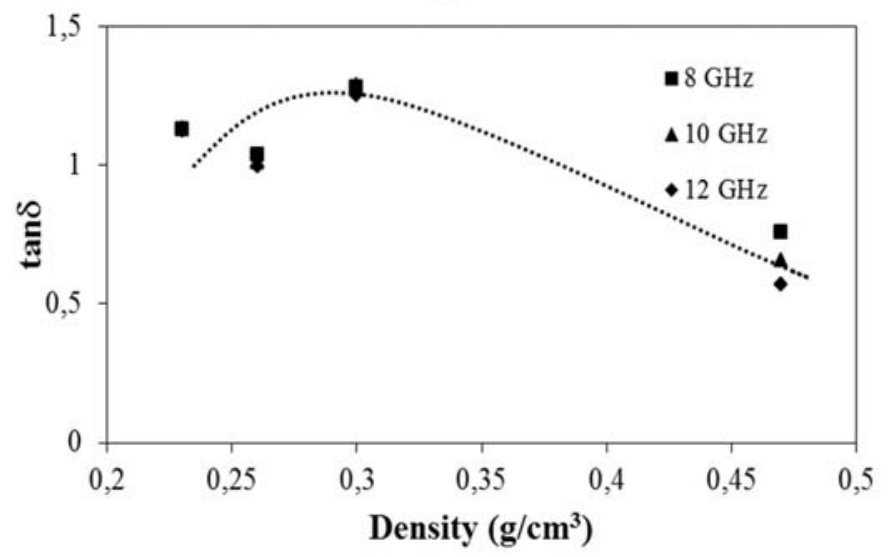

(b)

Fig 7 


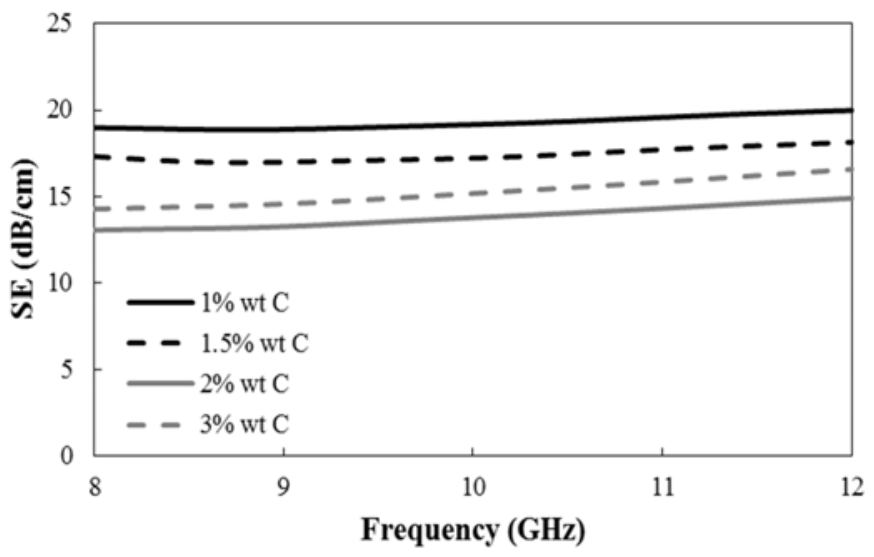

Fig. 8 .

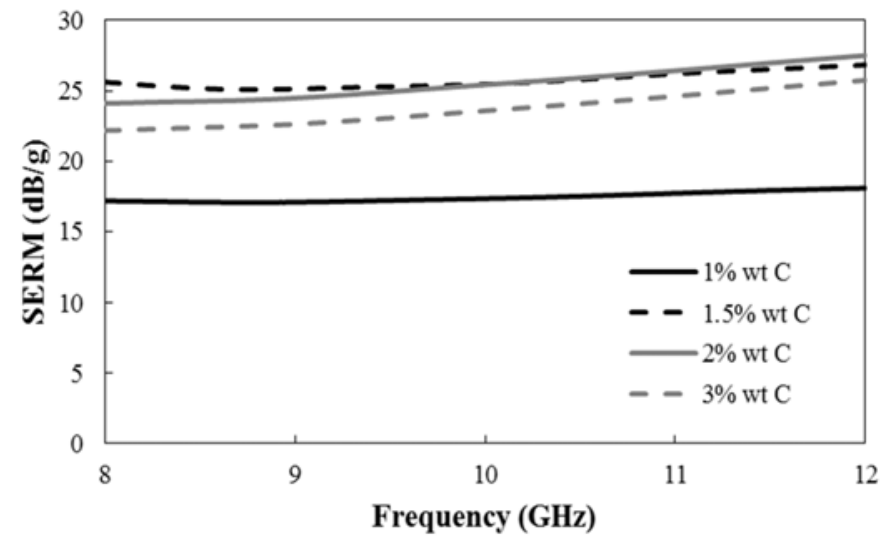

Fig. 9 


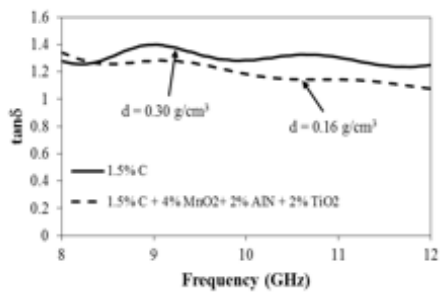

(a)

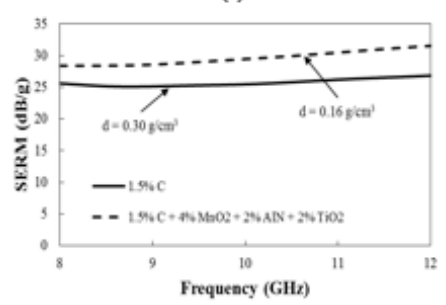

(b)

Fig 10

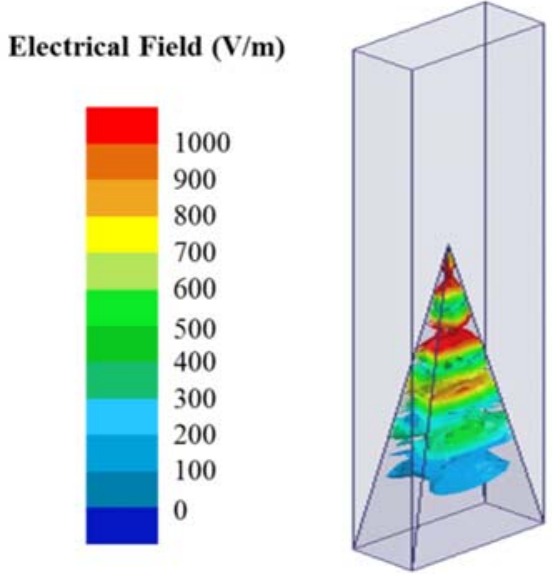

(a) 


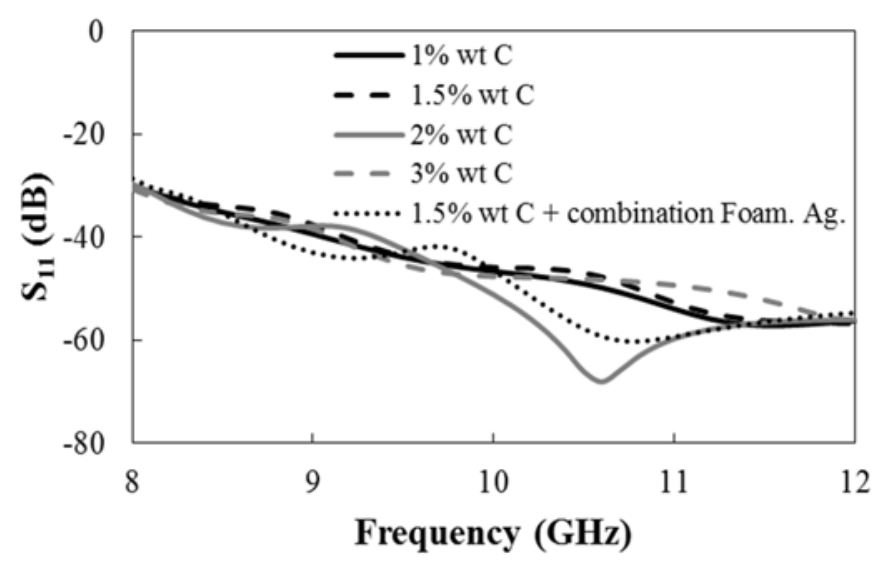

(b)

Fig. 11 
Table. 1. Synthesis parameters (cullet type and foaming agents) and density of the glass foam samples.

\begin{tabular}{ccccc}
\hline Glass cullet & $\begin{array}{c}\text { Carbon load rate } \\
(\mathbf{w t} \%)\end{array}$ & Others foaming agents & $\begin{array}{c}\text { Density } \\
\mathbf{( g / \mathbf { c m } ^ { 3 } )}\end{array}$ & Comments \\
\hline CRT & 0.5 & - & 0.58 & Too brittle to be measured \\
\hline CRT & 1 & - & 0.47 & - \\
\hline CRT & 1.5 & - & 0.30 & - \\
\hline CRT & 2 & - & 0.23 & - \\
\hline CRT & 3 & - & 0.26 & - \\
\hline CRT & 5 & - & 1.76 & No foaming process \\
\hline CRT & 1.5 & $\begin{array}{c}\mathrm{MnO}_{2}\left(4 \mathrm{wt}_{0}\right)+\mathrm{AlN}(2 \\
\mathrm{wt} \%)+\mathrm{TiO}_{2}(2 \mathrm{wt} \%)\end{array}$ & 0.16 & - \\
\hline
\end{tabular}

